Paideusis

\title{
"But are we going to deal with the hard questions?": Waves of Compassion in Halifax Regional Municipality
}

\author{
Susan Walsh, Fabiana Gonzalez, Phillip Joy et Kim MacAulay
}

Volume 21, numéro 2, 2014

Working Compassion

URI : https://id.erudit.org/iderudit/1071566ar

DOI : https://doi.org/10.7202/1071566ar

Aller au sommaire du numéro

\section{Éditeur(s)}

Canadian Philosophy of Education Society

ISSN

0838-4517 (imprimé)

1916-0348 (numérique)

Découvrir la revue

Citer cet article

Walsh, S., Gonzalez, F., Joy, P. \& MacAulay, K. (2014). "But are we going to deal with the hard questions?”: Waves of Compassion in Halifax Regional

Municipality. Paideusis, 21(2), 55-70. https://doi.org/10.7202/1071566ar
Résumé de l'article

Within broader social concern about compassion and learning to live well together in the world, a non-profit community-based organization called Waves of Compassion has emerged in Halifax Regional Municipality (HRM) in Nova Scotia, Canada. In this article, we explore how compassion relates to some "hard questions" that have arise for the organization—questions related to issues of marginalization and inclusivity: for example, what it might mean to "walk in another's shoes," particularly when that person or group of people is different from you in terms of age, race, ethnicity, sexual orientation, socioeconomic status, or citizenship. We also wonder what role the Waves organization might take up in terms of action and/or practice with regard to transforming inequity and promoting inclusivity in the community. We consider such questions in the context of data derived from a recent survey that Waves of Compassion undertook. We integrate found poems (many of which are derived from the survey data) and expository writing as means of underlining what some writers have said about compassion - that it involves both emotions and rational thought, the undoing of sharp distinctions between the two. We see compassion as a form of practice where boundaries and separations might be dissolved (at least at times) through being and knowing in different ways. (c) Susan Walsh, Fabiana Gonzalez, Phillip Joy, Kim MacAulay, 2014

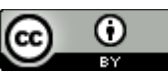

Ce document est protégé par la loi sur le droit d'auteur. L'utilisation des services d'Érudit (y compris la reproduction) est assujettie à sa politique d'utilisation que vous pouvez consulter en ligne.

https://apropos.erudit.org/fr/usagers/politique-dutilisation/ 


\title{
"But are we going to deal with the hard questions?": Waves of Compassion in Halifax Regional Municipality
}

\author{
SUSAN WALSH, FABIANA GONZALEZ, PHILLIP JOY, \& KIM MACAULAY \\ Mount Saint Vincent University
}

\begin{abstract}
Within broader social concern about compassion and learning to live well together in the world, a non-profit community-based organization called Waves of Compassion has emerged in Halifax Regional Municipality (HRM) in Nova Scotia, Canada. In this article, we explore how compassion relates to some "bard questions" that have arise for the organization-questions related to issues of marginalization and inclusivity: for example, what it might mean to "walk in another's shoes," particularly when that person or group of people is different from you in terms of age, race, ethnicity, sexual orientation, socioeconomic status, or citizenship. We also wonder what role the Waves organization might take up in terms of action and/ or practice with regard to transforming inequity and promoting inclusivity in the community. We consider such questions in the context of data derived from a recent survey that $W$ aves of Compassion undertook. We integrate found poems (many of which are derived from the survey data) and expository writing as means of underlining what some writers have said about compassion - that it involves both emotions and rational thought, the undoing of sharp distinctions between the two. We see compassion as a form of practice where boundaries and separations might be dissolved lat least at times) through being and knowing in different ways.
\end{abstract}

compassion is

"suffering with" we share our

stories of deep experiences truly

listening to each other this means

building an environment where people

feel safe to be vulnerable where we

can be open about what

matters to us deeply without

fear of being shamed through sharing

stories we develop understanding of

positions outside our own ${ }^{1}$

1 Throughout this article, we include short "found" poems, some derived from our research (survey) data and some from teachings and/or literature about compassion. We discuss our process of composing found poems later in the article.

(C) Copyright 2014. The authors, Susan Walsh, Fabiana Gonzaler, Phillip Joy \& Kim MaCaulay, assign to Paideusis the right of first publication and educational and non-profit institutions a non-exclusive license to use this document for personal use and in courses of instruction provided that the article is used in full and this copyright statement is reproduced. Any other usage is probibited without the express permission of the author. 


\section{Introduction}

In recent years, an increasing global wave of conferences, gatherings, discussion groups and networks have coalesced around the need for compassion as a way of being in the world. People are becoming increasingly alienated from themselves, each other, and the natural world; discourses about the individual, accountability, competition, and entrepreneurship advanced through the dominance of neoliberalism as the global socioeconomic mainstay are becoming more and more inadequate in the face of worldwide environmental degradation, widening gaps between those living in poverty and those who are most economically privileged, human rights atrocities in and beyond the context of war, political upheavals, the predominance of technology as a way of relating together and so on. Many people are searching for different ways of being in the world, some sort of global shift in consciousness that involves greater concern with how we might live well together; words like care, empathy, altruism and compassion are increasingly evident in research and scholarship in various areas (see, for example, Blackstone, 2009; Eppert, 2010; Levenson, 2009; Mercadillo, Diaz, Pasaye \& Barrios, 2011; Mongrain, Chin \& Shapira, 2001; Oveis, Horberg \& Keltner, 2010; Rigoni, 2007; Segal, 2011; Trueland, 2012; Vitellone, 2001; Whang \& Peralta, 2005). Scientists and researchers working with compassion are now regularly featured in widely circulated internet videos: among these, contemplative neuroscientist Richard Davidson (2012), molecular biologist and developer of mindfulnessbased stress reduction (MBSR) programs, Jon Kabat-Zinn (ex. Kabat-Zinn \& Doty, 2011) and selfcompassion researcher Kristin Neff (ex. Neff, 2009, 2011, 2012; Neff \& McGehee, 2010; Neff \& Vonk, 2009) (see also CCARE, 2012; Mind \& Life, 2013). The Mind \& Life Institute has recently advanced concern with compassion in relation to its research agenda; their website states, "we are interested in the nature of compassion as the basis for ethical conduct, and in how we can better nurture compassion in education and other social institutions" (Mind \& Life, 2013). Scholar of world religions, Karen Armstrong (2011) and her work in leading an interfaith team to develop the Charter for Compassion (http://charterforcompassion.org/) (see also the Canadian Charter for Compassion, http://canadians4compassion.org/) and the subsequent proliferation of the Compassionate Action Network (http://compassionateaction.org/) has intensified discussion and action in the form of individual and social practices among broader and more diverse groups of people worldwide. Within this larger social movement, a non-profit community-based organization called Waves of Compassion (Waves) (see Waves of Compassion, 2013) has emerged in Halifax Regional Municipality (HRM) ${ }^{2}$ in Nova Scotia, Canada to explore the ways that we might live, work, and play together more compassionately.

Originally motivated by the Compassionate Cities initiative and further inspired by an on campus program called "Heart and Spirit of Our Communities" at Mount Saint Vincent University (MSVU), Spiritual Life Coordinator, Kim MacAulay, and faculty Susan Walsh and Sherry Hassanali began to plan ways of involving community members in a compassion initiative for HRM. Through initial conversations in early 2012 - which included members of the public from a broad range of sectors such as health care, education, religion, the military, policing, government, and people involved with volunteer work and non-governmental organizations-we began to ask what does "compassion" mean? And, what are some examples of our own experiences with compassionate acts? Curiosity about compassion-and how different people perceive itdeveloped into a collective desire to ask how we might practice compassion more consciously, both within the Waves organization and also in the wider HRM community. At the fourth meeting of this young organization, in June 2012 - a meeting that was attended by approximately 35 people from different spiritual, racial, and cultural groups as well as people who were born in Canada, and those who have immigrated, and people from various workplace contexts - a community member asked whether or not we were going to ask the "hard questions" in the work of the Waves organization. It seems important to note that the person who asked the question is a person of colour, given that that others in the room who are members of nondominant social groups, including those from the First Nations community, vigourously added their support

\footnotetext{
2 Situated on the Atlantic coast along a natural harbor, and with a current population of approximately 400, 000 (HRM, 2013), Halifax Regional Municipality, which includes Halifax, Dartmouth, Bedford, and the former Halifax County is the largest urban center of Canada's four easternmost provinces.
} 
to her query. ${ }^{3}$ Further, the question arose against the backdrop of news about government cuts to refugee health services (see, for example, Galloway, 2012) and also the murder of Raymond Taaval, a strong gay activist in HRM (Nycum, 2012; Wong, 2013). ${ }^{4}$ A discussion about racism, marginalization, and inequity in the community ensued, and the illusion, if anyone was operating under it, that compassion is about just feeling good- "yellow smiley faces"-was immediately dispelled. A member of the Waves leadership team brought this discussion, and the meeting, to an end by inviting us to reflect on how we might relate with righteous anger about inequity as we work with compassion. The leadership team has continued to reflect on this discussion as it highlights the complexity of compassion and the challenges of being present to whatever arises in ways that enhance life for all.

compassion is reaching

out beyond the boundaries of your

own self protection to feel others'

pain and act as though the other

is your mother sister brother father

approaching every person and

situation without judgment staying

open to all possibilities and

outcomes making every

effort to be inclusive

The issue of "hard questions," why people, especially those with social privilege, tend to avoid such questions, and how we might address them compassionately is one that has lingered for the Waves organization. The importance of addressing issues of marginality and inequity was further underscored by responses to a survey at a gathering organized by the $W$ aves organization in March 2013: Celebrate a Culture of Compassion: Community, Commitment, and Challenge. 5 A hundred people, mainly from HRM and other parts of Nova Scotia, attended the gathering, the purpose of which was to explore what compassion means to different people and to consider what we might do to nurture compassion in our communities. In response to the survey, ${ }^{6}$ a significant number of community members wrote about inclusivity and the need for dialogue

${ }^{3}$ While it is beyond the scope of this paper to fully outline Halifax's and Nova Scotia's history that with respect to the marginalization of people, we do feel that the following at least need to be acknowledged in order to provide some context. Nova Scotia was built on land first known as Mi'kma'ki (Nova Scotia Office of Aboriginal Affairs, 2013), home of the Mi'kmaq people. In the late 1500s, the French, in search of fish and furs, landed north of HRM, around Louisbourg, but many sailed into the Bay of Fundy after a harsh winter and founded Annapolis (Port) Royal, the heart of Acadia in western Nova Scotia (see Bruce, 1997, for a history of Nova Scotia). The British, expanding their colony in the future United States, eventually took possession of Acadia and established their base in Halifax in the late 1700's. Subsequent historical events checker Nova Scotia's history (including that of HRM) and underscore its present day context, particularly with respect to groups who have been marginalized because of race and/or ethnicity. For example, during the period of 1755-1764, the British loaded the Acadians onto ships and transported them to the American coastal areas, and also later, to France in what has become known as the expulsion of the Acadians. Allowed back into Nova Scotia in 1764, the Acadians settled around the western shore and Cape Breton. First Nations people, after a series of treaties in 1760, were forced to live on reserves owned by the Government of Canada. Further, after the American Revolution, many people migrated north to Canada, some settling in Nova Scotia. Many of the people of African descent who settled in Halifax lived in an area known as Africville, an area of the city that was razed in the 1960's as part of an "urban renewal” project (see Africville Genealogy Society, 2010).

4 Taavel was tragically killed by Andre Denny, a member of the Mi'kmaq community. Denny, who has schizophrenia, was on an unescorted hour-long hospital leave at the time. In the media and in the community, people reflected on offering compassion to the perpetrator, as well as to the offended.

${ }^{5}$ The Waves organization offers an overview of the March 2013 gathering at http://www.wavesofcompassion.ca/whathappened.html. Photos and video of the event are also available on the website.

${ }^{6}$ Sixty-five percent of the participants at the March 2013 gathering responded to the survey which included three main questions: i) What does "compassion" mean to you? ii) Describe a compassionate act that you were involved with or that you witnessed. iii) How can we make Halifax Regional Municipality a more compassionate place to live and work? 
among all different groups of people in HRM. For example, respondents noted concern for people who do not have permanent homes ("the homeless") and/or those who are living in poverty, those who are aged, physically or mentally ill, youth, people with disabilities, people from non-dominant racial, ethnic, religious/spiritual groups, and those who have immigrated to Nova Scotia. The theme of connecting with others emerged through references to inclusivity, care for others, and aspirations about non-judgment, openness and respect. A number of people wrote variations on the saying (credited to origins in North American Indigenous culture) that we should not judge others until we have "walked a mile in their shoes."

\section{Our Approach and Intents}

In this paper we explore how compassion relates to "hard questions," issues of marginalization and inclusivity-what it might mean to "walk in another's shoes," particularly when that person or group of people is different from you in terms of age, race, ethnicity, sexual orientation, socioeconomic status, or citizenship, for example. Is it even possible (or desirable) to walk in another's shoes? We wonder too what role the Waves organization might take up in terms of action and/or practice and making a difference with regard to inequity and inclusivity in the community. What might this mean, given the composition of the leadership team? (Of ten active members on the leadership team, eight are women, and eight are White; eight are Canadian born, and two have immigrated to Canada. Most are aged fifty or older, and most are Christian or Buddhist.) Our overall intent in this paper is not to solve the issues or answer the questions we are asking, but rather to grapple with them in the context of the responses from community members on the survey and also broader discussions about compassion in the literature. We offer our scholarly exploration to the Waves of Compassion organization and other groups like them as part of ongoing conversations about practicing compassion. In doing so, we wish to say that the "we" that we (Fabiana, Phillip, Kim, and Susan) invoke in writing this paper is not a homogeneous whole, nor do we speak for the Waves of Compassion Association or its leadership team. Kim and Susan, however, are longstanding members of the leadership team, and Kim is also now an executive co-director of the organization. Together, Kim and Susan hold a small grant from MSVU that has enabled the research with $W$ aves. Fabi and Phillip are student research assistants who have been involved with the research and the organization for some time. "We" four are all White, highly educated, middle class people: Susan, Kim, and Phillip are Canadian born, and Fabiana is a Latin person with European ancestry. Susan and Kim identify as Buddhist, Fabiana as Agnostic.

ask someone from the West

Where is the mind? most often

that person will point to the head ask

the same person Where is the heart? the

place they feel things and they will point

to their chest we don't find this in all

cultures a Tibetan for instance will not separate

mind and heart in the same manner if you ask

a Tibetan to locate mind they will most

The five major themes that emerged from the data include: i) self in relation to others (includes notions of inclusivity, non-judgement, openness, tolerance and respect towards others), ii) working for the greater good (shared humanity, going beyond self, letting go of ego to work towards a greater good-which involves not only humans, but animals and nature/the environment), iii) feeling/heart vs. intellectual views on compassion (many of the words used to describe what compassion means were words such as love, kindness, caring, heart, and less frequently wisdom, energy, forgiveness, soul, empathy and gratitude), iv) compassion and action (many action examples were dialogic such as deep listening and sharing stories; connective such as working together and promoting a sense of community; and also of a" helpful" nature such as giving back, offering help and assisting others, v) compassion starts with the self (being compassionate towards others requires that one must first be compassionate to oneself). 
likely point to their chest

the Tibetan word nyingje or "compassion"

refers to both thought and feeling if we don't

understand the interdependence of

heart and mind we can't use either to

its fullest potential when we separate clear reasoning

from experience our emotional and

conceptual life runs amok in truth beyond cultural

interpretation we can't actually separate experience

from awareness heart and mind are

linked in that experience and awareness arise in

dependence upon one another when we engage

mind through a process of subjective inquiry we naturally

include our emotional spiritual physical conceptual life

(the above two stanzas found in Mattis-Namgyel, 2008, pp. vii-viii)

compassion is awakened heart and mind

a heart that stays open and accepting in the

face of suffering that radiates joy a mind that

takes in every facet of our world with clarity wisdom

In grappling with "hard questions" amidst the background of our own privileged social locations and also in attempting to find respectful ways of engaging with the responses offered by the community members who participated in the survey, we have evolved a process of writing together that includes the use of found poems. A found poem is a poem "found" from words and phrases in the environment that are then (re)arranged in particular ways - in this paper, the words and phrases in our poems come from the responses to the surveys and from texts we have read about compassion. 7 Many of the found poems derived from the survey data are composites in the sense that they come from the replies of a number of people. The use of found poems as a means of working with data and other research artifacts has been well-documented in recent years (see, for example, Butler-Kisber, 2002; Prendergast, 2009; Richardson, 1992; Walsh, 2003, 2006). We find that the process of creating poems from the data and texts about compassion helps us move out of analysis (which we foregrounded in our initial coding of the survey data) and into a way of being and knowing that is more lyrical and embodied. We feel a different connection and sensitivity to what the respondents expressed, for example, through periods of intensive attention to and engagement with the words, we listen differently. This feels important given our work with compassion. We offer our poems and expository writing together as means of underlining what some writers have said about compassion - that it involves both emotions and rational thought, the undoing of sharp distinctions between the two. American philosopher Martha Nussbaum (1996), for example, says that compassion is not solely an emotion, "some mindless non-cognitive force" (p. 44); it also involves "a certain sort of reasoning" (p. 28)—thus it is an emotion that involves thought and evaluation. We are interested in those who seek to undo dualisms such as reason and emotion ${ }^{8}$ and will talk further (later in the paper) about dualisms, particularly as they relate to marginalization and inequity. We see compassion as a form of practice where boundaries and separations might be dissolved (at least at times) through being and knowing in different ways.

\footnotetext{
${ }^{7}$ Found poems that we have crafted from literature and/or teachings about compassion are followed by a reference in parenthesis; all other found poems come from the survey data.

${ }^{8}$ We are interested in investigating further the work of people like Damasio (1994) and Davidson and Begley (2012) who highlight the ways that emotion and rationality are interconnected.
} 


\section{Walking in Another's Shoes and the Roots of Separation}

compassion is the ability

to put oneself in another's

shoes in order to appreciate and sense

the feelings and experiences of

the other person rising above one's

own needs actual or perceived to carry

out acts that are of benefit to the other person

seeing through her/his eyes taking the

perspective of the other trying

to put yourself in their shoes

understanding their situation because of your common

experience to be able to put myself

in the shoes of the other

relating to the experience and feelings of

others so that we recognize and

suffer with them you don't

judge another person until you have

walked a mile in their shoes

How might we experience "walking in another's shoes"? And, is it possible to do so, given the differing ways that people are socially located? By assuming that we can walk in another's shoes, are we conflating difference? And what might this mean when the person stepping into another's shoes has social privilege of some sort? For example, can a highly educated, middle-aged woman of colour step into the shoes of a young, highly educated, Muslim woman who has recently immigrated to Canada? What do such questions mean for the Waves of Compassion organization and its role in the community, particularly given the current composition of the leadership team? In our attempts to better understand the roots of marginalization and inequity, we turn to feminist scholars such as Ruether (1992) and Tomm (1995) who trace the historical roots of separation and dualism in Western philosophical thought. They explore separation and duality-the pairing of "opposites" such as reason/emotion, male/female, White/Black, self/other-and contend that such pairings are anything but neutral and innocuous, particularly for certain groups of people. Lloyd (as cited in Whitford, 1991) goes back to the sixth century BCE and the Pythagorean table of opposites.

the Pythagoreans saw the world as

a mixture of principles associated with

determinate form seen as good and

formlessness the unlimited irregular disorderly seen

as bad inferior there were ten such contrasts

in the table limit/unlimited odd/even one/many

right/left male/female rest/motion straight/curved

light/dark good/bad square/oblong

'male' and 'female' like the other contrasted

terms did not here function as descriptive

classifications 'male' like the other terms on

its side of the table was construed as superior to

its opposite the basis for this

superiority was its association with the primary

Pythagorean contrast between form and formlessness

(found in Lloyd as cited in Whitford, 1991, p. 60) 
Theologian Rosemary Radford Ruether (1992) underlines the ways in which separation and hierarchization is apparent in the Greek creation story. Plato's Timaeus, she says, begins by "defining the primal dualism that underlies reality; its division into two realms, the invisible, eternal realm of thought and the visible realm of corporeality" (p. 22). Thought precedes "the unshaped matrix of visible being which Plato calls 'space' or "the nurse"" (p. 22). The Demiurgos or Creator then shapes the elements of earth, air, water, and fire as well as the cosmos, the world soul, and finally human souls and male bodies. Ruether underlines the subject/object distinction involved with "making" (pp. 22-23). Further, men are required to control the sensations of the body; he who succeeds will in death return to his "star"; "but if one fails to attain this control over the body and its sensations, the soul will be reincarnated and pass in a second birth into a woman," and upon further failures to a "brute" (p. 23). Ruether delineates two influential assumptions emanating from the Greek story. First, reality is divided between mind and body and that mind is divine, godlike, and the body (including the emotions) is "secondary, derivative, and the source of evil" (p. 24). Second, the mind/body dualism is a model for the hierarchical preeminence of man over woman and human over animals (and the natural world); it forges other human class divisions (see Ruether, 1992, pp. 15-31; Tomm, 1995, pp. 116-121). Such classical views (at least in Western culture), she says, underline "assumptions about the nature of the world, physical processes, and their relationships, but they are also blueprints for society" (p. 15).

feeling safe enough to trust that I can fully express my race gender religion spirituality approaching every person I encounter with out judgment staying open to all possibilities and outcomes making every effort to be inclusive appreciate sense the feelings and perceptions of the other person being able to hear with both heart and mind open non judgmental patient hear each other feel love do no harm treating yourself and others with kindness open heart and love creating an environment for people to express and live their truth without judgment not judging people by looks or clothes or country of origin a mindset to treat each other at a very basic human level and getting away from the barriers of race ethnicity colour languages

The mind/body split and the superiority/transcendency of mind as described by Plato is further entrenched by later philosophers. Tomm (1995) points to Descartes as an example: Descartes' theory espouses the belief that the mind of God is the foundation for knowledge and that such knowledge can be revealed to man through specific methods of logical inquiry (p. 118). Tomm says that Descartes' "method of reasoning in the seventeenth century . . . is an attempt to reconcile the tensions between religious and scientific authority" ( $p$. 118) and reminds us that it is "important to determine the relations between the interests of dominant groups and the so-called 'truths' revealed by logic" (p. 118). Crucial to our work in addressing hard questions in the work of Waves of Compassion is the acknowledgement that Western thought (and institutions) have been structured in particular ways for hundreds of years - and that separations based on hierarchized dualities are key features of that thought—as is the resultant systemic inequity for particular groups of people and the separation between humans and the other-than-human world. ${ }^{9}$ Such separations and hierarchies are important to our discussion as they shape possibilities for how we might relate with each other and the world in compassionate ways. Segal (2011), in discussing her work with social empathy states that, "without an understanding of complex social conditions, individuals are more prone to believe stereotypes and emotionally appealing rationale that can lead to ideological scapegoating" (p. 268). Further questions emerge: how do we live outside of these social structures, given that they shape our being and knowing? What, for

9 Even the emphasis on "thought" in this discussion underlines the mind/body dualism so prevalent in Western philosophy. Please see the discussion based on Ruether (1992) above. 
example, is the effect of the mind/body dualism on our lived experience? In what ways is the body (as distinguished from the mind in this dualism) shaped differently among privileged and marginalized groups? How does an understanding of the embeddedness of social structures then make "walking in another's shoes" much more complex than simply shifting positions?

the Cartesian self as the possessor of Mind

or Reason stands absolutely alone in the center

of the immense Mechanical Universe the universe

(in this view) is an absolute Other to the self since

there is no sense of consanguinity and communion between

$I$ as a person and the depersonalized word of objects

my foremost way of being in the world is alienation

domination possession existential

lack is at the root of the

problem of dualistic consciousness

(found in Bai, 2001, p. 7)

people who are different from

ourselves separate from my story those who are

without family the disenfranchised with

needs that are not being met people

with disabilities we need action

for our homeless having showing

mercy handed down from on high look

at the needs of the most vulnerable

people with disabilities including invisible

disabilities neurological diversity understanding that

youth have needs that are not being met people treating

me like a person and taking the extra time to listen

remembering that I have hopes and fears treating me

like an able person demyth negative stories about

immigrants disadvantaged youth aging people

homeless mentally ill more diversity in organizations

\section{Some Views of Compassion and the Relationship between Self and Others}

While we wish to honour the responses of community members who call for inclusivity in HRM and beyond, we also feel that that legacy of dualistic thinking-including that between self and other-must be acknowledged and explored as its roots run deep and are evident in discussions about compassion in the literature. If one is perceived as separate from another, then what does it mean to be compassionateparticularly if the self and other are different in terms of social location? How might compassion be experienced differently if relationship and interrelationship is foregrounded in the ways we think about and live with others and the natural world?

Nussbaum (1996), a liberal humanist, articulates a view of compassion that "takes up not the actual view of any and every sufferer, but rather the point of view of a reflective spectator who asks which reversals [of fortune] are of true importance and which are not" (p. 45). Her view of compassion is shaped by her view of the "self" as a contained and reasoning entity separate from others, though living with them in a social context-such a self can act as a "reflective spectator" (p. 45) or a "compassionate spectator" (p. 51) in 
relation to another. ${ }^{10}$ She equates pity with compassion, noting their historical and language-based roots, and stating that she uses the word "compassion" when referring to contemporary contexts because the word "pity," "has acquired nuances of condescension and superiority to the sufferer that it did not have formerly" (p. 29). ${ }^{11}$ The separation between self and other surfaced in some of our survey responses too. One person, for example, wrote, "My immediate thought on the word [compassion] is to say having mercy . . . this thing that is handed down from on high, a judge, an employer, for example... but the word, the idea, the action is something more complex." Other respondents indicated groups of people who are oppressed in HRM such as "the disenfranchised, those with disabilities," "the most vulnerable," "youth, " the aged" and so on. How do we walk respectfully and compassionately in the shoes of those whom we have identified as "different from me"?

At the risk of reinforcing another dualism, we offer the views of writers such as Walsh-Frank (1996) and Yao (2006) who contrast so-called "Western" views of compassion ${ }^{12}$ in relation to understandings about the self-other relationship-particularly those with clear-cut distinctions between the self and others-with Buddhist views about non-duality and compassion (see also Eppert, 2010). In Buddhism, says Yao (2006), "all life is equal because all sentient beings have the same Buddha-nature"-the same non-dual consciousness. The "self" as a coherent, stable, and boundaried being is an illusion based on attachment to ego. WalshFrank (1996) says that the ego-centred person

sees himself an independent ruler of his life and as a powerful person who has some control over the impermanence...of all things.... He has a right to ownership of the things of this world just as he clings to these very beliefs himself.... [He is] concerned with the satisfaction of [his] own desires without consideration, oft times of others. (p. 4)

"Ego" develops through the misrecognition of itself as separate from primordial spaciousness, thus solidifying form and initiating duality— the differentiation between self and other, perceiver and perceived, and so on, thereby strengthening the illusion of separateness and obscuring the original state of being (Trungpa, 1973). The basis of suffering-the attachment to the illusion of a separate self-is a universal human condition rather than a personal event or condition; it occurs because one is caught in the illusion of the self (ego). Vietnamese Buddhist teacher Thich Nhat Hanh (n.d.) describes the original non-dual state of being as "interbeing."

a flower cannot exist by

herself alone cannot be by

herself alone a flower has to

interbe with the sunshine with

\footnotetext{
${ }^{10}$ Feminist writer Laura Cannon (2005) questions Nussbaum's work and its implicit view of compassion and of self in relation to others. Implicit in Cannon's argument is a view of the "self" as socially constructed and contextual; she questions the three conditions that ground Nussbaum's (1996) view of compassion and refutes the view that compassion is based on objective and universal principles; instead she calls for a "thick" understanding of others, an appreciation for human complexity (pp. 103-104), rather than universal guidelines about what compassion entails. She emphasizes the importance of understanding how particular social norms inform and construct compassion in particular sociocultural and historical contexts.

11 See also Armstrong (2011, p. 8) and Eppert (2010) for further notes about the connection between pity and compassion.

12 Each of these writers discuss different views as representing the "West"; Walsh-Frank (1996) concentrates on an essay by Blum, and Yao discusses a few writers including Nussbaum (via a critique by Conway). He says that "since Nussbaum's account follows Aristotle and since Aristotle is one of the most important Western philosophers, it is fair to assume that Nussbaum's account is adequate to represent the general Western view of compassion" (2006, p. 196). Homogenizing the "West" and conflating its wide range of views is clearly problematic. However, elaborating on all of them is also well beyond the scope of this paper (as is differentiating among Eastern wisdom traditions, even different forms and lineages of Buddhism). Our overall point is that it is worth considering how the self is viewed in relation to the other - as this relationship makes a difference as to how compassion is embodied and enacted.
} 
the clouds with the rain with

the soil so we are also like

a flower we cannot be by

ourselves alone we have to

interbe with our father our

mother our ancestors our culture our

food the air the water and so on

(found in Hanh, n.d.)

living in oneness

interconnected to all

life in relationship to

self others and the world

reaching out

beyond personal boundaries

understanding our

common experience

we are not alone

in this world we are

not strangers

feeling love toward

everyone treating

yourself and others

with kindness generating

greater good understanding that

we are all in the same

boat we are all connected and the

individual pain that people experience

on some level affects us all living

in oneness with all the Earth and the Universe

we think differently but that does not

mean it is "wrong" just different we all have

our sorrows and sufferings and there is no

way to measure whose is more important or

whose is worse connection with

earth all beings suffering of the individual the whole

Tibetan Buddhist teacher Trungpa Rinpoche (1991) undoes the self-other (and also inner-outer) dualism in teaching about our other and the other other. The other does not exist outside ourselves, the two are interrelated. So, one aspires to be open-and willing to help others like oneself.

We are no longer intent on creating comfort for ourselves; we work with others. This implies working with our other as well as the other other. Our other is our projections and our sense of privacy and longing to make things comfortable for ourselves. The other other is the phenomenal world outside, which is filled with screaming kids, dirty dishes, confused spiritual practitioners, and assorted sentient beings. (Trungpa, 1991, p. 109)

We experience the other within ourselves - a different way of relating. We need to acknowledge and relate with our differences, and also reflect on what we have in common. As Buddhism suggests, all humans (and other beings) want to be happy and free from pain and suffering. If so, could this be a basis for our common 
experience? Can we imagine what it is like to be in someone else's shoes from the viewpoint of wanting to be happy and free from suffering? And what communication tools do we need to cultivate in order to truly hear, understand and appreciate another's perspective? Buddhist nun, Pema Chödrön (2012) underlines the difficult work of being compassionate, of being unequivocally open to others and their suffering. ${ }^{13}$ In doing so, she invokes the "shoes" metaphor discussed above. She says,

Compassion is threatening to the ego. We might think of it as something warm and soothing, but actually it is quite raw. When we set out to support other beings, when we go so far as to stand in their shoes, when we aspire to never close down on anyone, we quickly find ourselves in the uncomfortable territory of "life not on my terms." (p. 65)

What does it mean to "never close down on anyone"- especially to someone who is different from oneself, or someone whose actions we find repugnant, even morally wrong? What if being open to others-if relating to them, listening to their stories, recognizing their suffering, their need-means changing one's own location? The willingness to be open to our own other and the other other is a difficult practice-something that requires a shift in being, the way we relate to ourselves, other people and the world. Something gentler, more open, more compassionate. And something that means we are willing to move out of ourselves, the "selves" we think we are. A pathway to working with the hard questions, something undertaken by everyone. Movements that might effect small transformations and more small transformations, a collection of which might effect larger social transformations-a pathway to addressing marginality and inequity in our community.

\section{Listening, Presence as "Action"}

encourage open and honest

dialogue and get to know

people who are different

from ourselves while listening

deeply bring compassion to organizations

workplaces hear and say

what really matters giving

more space time for sharing

interactions demyth negative

stories while understanding

social injustice bridge

generations day by day

working together

compassion is a feeling of love toward everyone also nature and all on the earth a feeling of peace and goodwill no judgment no ego treating the world and everyone in it not as strangers but as people we actually love and care about treating the world compassionately would mean you listen to everyone's story listen to one another

\footnotetext{
${ }^{13}$ Compassion is integral to Buddhist teachings; it is one of the Four Immeasurables and the heart of the bodhisattva path (see Chödrön, 2005; Eppert, 2010).
} 
When asked what we might do to make HRM a more compassionate place to live and work together, a significant number of respondents indicated the need for dialogue and listening. What does it mean to really listen? And, how does "really listening" relate to walking in an other's shoes? While we began our work with the survey data and writing this paper with the idea that compassion has an "action" component- that it is not just an emotion or even an emotion laced with reason, we now recognize through the wisdom of the survey respondents that what people from HRM are calling for is presence, a different way of being together in our community. An openness and willingness to listen with an open heart, especially, to stories that might be difficult to hear, stories that produce discomfort. Stories that have the potential to change how we relate to one another. The examples people shared show that listening and compassion, as one person wrote, "[do] not occur collectively without it occurring in each person's heart."

the executive manager of our church came to a large meeting of members who were invited to express unmet needs and disappointments as well as wishes ideas for improvement she did not have to attend she chose to even though difficult issues and emotions were expressed she was generous for the good of the whole situation a moment where I was weeping feeling my own sadness not being sure if I could stay with it my friend being silent but present encouraging me to do so compassion means giving space to suffering and feeling it our own suffering and that of others it means being with what is giving space to it

watching a close friend journey through mental illness seeing myself grow in compassion as I accompanied this person on the journey now witnessing the compassion he has for others going through their own struggle when a youth did harm the person harmed invited love into the situation attending an AIDS/HIV retreat in Ontario several years ago ten volunteers some scared about meeting and physical contact with AIDS/HIV positive patients watching the fear faced and compassion settle in

Whang and Peralta (2005) discuss the experience of "being present" at school. Given the increasing diversity in (North) American classrooms and the relative homogeneity of the teaching profession, making authentic connections can be difficult. People were invited to connect by sharing and keeping their minds open when listening, being present in the moment; "the method is mindfulness, the expression is compassion, and the essence is wisdom" (p. 81). They also note that "focusing on these qualities of spirit turns attention to the impact of one's actions on others and is important in a society where people are 'locked into an ethos of selfishness and materialism' habitually preoccupied with self or where the cultural norms tend toward individualism" (p. 89). Rigoni (2007) talks about compassion and solidarity, using the idea of fellowship. He shares stories of undocumented immigrants and how they find relief solely by being taken into account and being treated as human beings.

kindness cuts through isolation fear and aggression all of us can remember moments of kindness that changed our day maybe our lives when we relegate 
kindness to mere social courtesy we are handicapping our access to the ambassador of love and compassion deeply held powers of the human heart with kindness we will shift our future (found in Mipham, 2013, p.67)

I like the metaphor of sitting beside when we sit beside we are able to be with that person as they are at that moment in that space without judging but feeling

Our process of writing this paper-encountering and thinking through the differing views about compassion-inspired questions for us about our unarticulated ways of being in relation to "others." Exploring ideas collaboratively through expository writing and also creating found poems from the survey responses and the literature about compassion has offered us an opportunity to reflect at length together about what it might mean for the Waves of Compassion organization to address "hard questions" in Halifax Regional Municipality. The voices of the survey respondents spoke loudly to us-people want to engage in authentic and real conversations. They want to share stories-be present, offer presence, feel the presence of others in a real way. We (as part of the $W$ aves organization) have yet to know what this might mean as more and more stories are told. For now, it seems important to hold a sense of shared humanity together with an ongoing willingness to recognize difference, so that such differences are not erased or dismissed, acknowledging as Pema Chödrön (2012) says above, that compassion is raw, and that recognizing differences might mean living in the "uncomfortable territory of "life not on my terms" (p. 65)—or, in my own shoes. This means problematizing what "inclusivity" might entail. We offer our scholarship, in the form of this paper, as one step on the path.

\section{Acknowledgments}

We gratefully acknowledge the efforts of those who responded to the Waves of Compassion survey. We also thank Mount Saint Vincent University for awarding us a Community Connections and Creative Research Communications grant.

\section{References}

Africville Genealogical Society (2010). Africville: The spirit lives on. Accessed September 25, 2013 at http://www.africville.ca/index.html

Armstrong, K. (2011). Twelve steps to a compassionate life. Toronto: Vintage Canada.

Bai, H. (2001). Challenge for education: Learning to value the world intrinsically. Encounter: Education for Meaning and Social Justice, 14(1), 1-13.

Blackstone, A. (2009). Doing good, being good, and the social construction of compassion. Journal of Contemporary Ethnography, 38(1), 85-116.

Bruce, H. (1997). An illustrated history of Nova Scotia. Nova Scotia: Province of Nova Scotia and Nimbus Publishing.

Bulter-Kisber, L. (2002). Artful portrayals in qualitative inquiry: the road to found poems. Alberta Journal of Educational Research, 48(3), 229-239. 
Cannon, L. (2005). Compassion: A rebuttal of Nussbaum. In B. Andrew, J. Keller, \& L. Schwartzman (Eds.), Feminist interventions in ethics and politics: Feminist ethics and social theory (pp. 97-11). Toronto: Rowman and Littlefield Publishers, Inc.

Centre for Compassion and Altruism Research and Education (CCARE). (2012). Accessed August 16, 2013 at http://www.stanford.edu/group/ccare/cgi-bin/wordpress/

Charter for Compassion. (2012). Accessed August 16, 2013 at http://charterforcompassion.org/

Charter for Compassion Canada. (2013). Accessed October 10, 2013 at http://canadians4compassion.org/

Chödrön, P. (2005). No time to lose: A timely guide to the way of the Bodhisattva. Boston: Shambhala.

Chödrön, P. (2012). Living beautifully with uncertainty and change. London: Shambhala.

Compassionate Action Network. (n.d.). Accessed August 16, 2013 at http://compassionateaction.org/)

Damasio, A. (1994, October). Descartes' error and the future of human life. Scientific American, 144.

Davidson, R. (2012). Contemplative neuroscience. Meng Wu Lecture, Stanford University. Accessed April 10, 2013 at http://www.mindful.org/the-science/the-emergence-of-contemplative-neuroscience

Davidson, R., \& Begley, S. (2012). The emotional life of your brain. Toronto: Penguin Group.

Eppert, C. (2010). Heartmind literacy: Compassionate imagining and the Four Brahmaviharas. Paideusis, 19(1), 17-28.

Galloway, G. (2012). Ottawa softens hardline stance on medical treatment for refugees. Accessed July 3, 2012 at http://www.theglobeandmail.com/news/politics/ottawa-softens-hardline-stance-on-medicaltreatment-for-refugees/article4386163/

(HRM) Halifax Regional Municipality. (2013). Community: Community demographics. Accessed July 10, 2013 at http://www.halifax.ca/community/fact1.html

Hanh, T. N. (n.d.). I see you in me, and me in you: Interbeing with Thich Nhat Hanh. Accessed August 5, 2013 at http://www.youtube.com/watch?v =azOZ8d0UvVs

Kabat-Zinn, J. \& Doty, J. (2011). Conversation on compassion. Centre for Compassion and Altruism Research and Education (CCARE), Stanford University. Accessed May 14, 2013 at http://www.mindful.org/Mindfulness\%20and\%20Awareness/ccare

Levenson, M. R. (2009). Gender and wisdom: The roles of compassion and moral development. Research in Human Development, 6(1), 45-59.

Mattis-Namgyel, E. (2008). Editor's preface. In D. Kongtrül, Light comes through (pp. vii-ix). Boston: Shambhala.

Mercadillo, R. E., Diaz, J., Pasaye, E. H., \& Barrios, F. A. (2011). Perception of suffering and compassion experience: Brain gender disparities. Brain And Cognition, 76(1), 5-14.

Mind \& Life Institute. (2013). Ethics, education, and human development. Accessed August 16, 2013 at http://www.mindandlife.org/research-initiatives/

Mipham, S. (2013). The Shambhala principle: Discovering bumanity's bidden treasure. New York: Harmony Books.

Mongrain, M., Chin, J., \& Shapira, L. (2011). Practicing compassion increases happiness and self-esteem. Journal of Happiness Studies, 12(6), 963-981.

Neff, K. (2009). Self compassion: A healthier way of relating to yourself (website). Accessed September 23, 2013 at http:/ /www.self-compassion.org/

Neff, K. (2011). Self compassion: Stop beating yourself up and leave insecurity bebind. London: Hodder \& Stoughton.

Neff, K. D. (2012). The science of self-compassion. In C. Germer \& R. Siegel (Eds.), Compassion and wisdom in psychotherapy (pp. 79-92). New York: Guilfold Press.

Neff, K. D., \& McGehee, P. (2010). Self-compassion and psychological resilience among adolescents and young adults. Self \& Identity, 9(3), 225-240.

Neff, K. D., \& Vonk, R. (2009). Self-compassion versus global self-esteem: Two different ways of relating to oneself. Journal of Personality, 77(1), 23-50.

Nova Scotia Office of Aboriginal Affairs. (2013). Aboriginal people in NS. Accessed July 10, 2013 at http://www.gov.ns.ca/abor/aboriginal-people/ See also http://www.gov.ns.ca/abor/aboriginalpeople/demographics/

Nussbaum, M. (1996). Compassion: The basic social emotion. Social Philosophy and Policy, 13(1), 27-58. 
Nycum, B. (2012). What Raymond Taavel would have said about his killer (blog post 04/18/2012). Huffington Post. Accessed September 20, 2013 at http://www.huffingtonpost.ca/benjie-nycum/raymondtaavel_b_1434774.html

Oveis, C., Horberg, E. J., \& Keltner, D. (2010). Compassion, pride, and social intuitions of self-other similarity. Journal of Personality \& Social Psychology, 98(4), 618-630.

Prendergast, M. (2009). Introduction: The phenomena of poetry in research. In M. Prendergast, C. Leggo, \& P. Sameshima (Eds.), Poetic inquiry: Vibrant voices in the social sciences (pp. xix-xli). Boston: Sense Publishers.

Rigoni, F. M. (2007). Compassion and solidarity. Social Work in Health Care, 44(1-2), 17-27.

Richardson, L. (1992). The consequences of poetic representation. In C. Ellis \& M. Flaherty (Eds.), Investigating subjectivity (pp. 125-137). London: Sage.

Ruether, R. R. (1992). Three classical creation stories. Gaia and God: An ecofeminist theology (pp. 15-31). San Francisco: HarperSanFrancisco.

Segal. E.A. (2011). Social empathy: A model on empathy, contextual understanding, and social responsibility that promotes social justice. Journal of Social Service Research, 37, 266-277.

Tomm, W. (1995). Bodied mindfulness: Women's spirits, bodies and places. Waterloo, ON: Wilfrid Laurier Press.

Trueland, J. (2012). Compassion for keeps. Nursing Standard, 27(2), 20-22.

Trungpa, C. (1973). Cutting through spiritual materialism (J. Baker \& M. Casper, Eds.). London: Shambhala.

Trungpa, C. (1991). The heart of the Buddha. (J. Lief, Ed.). London: Shambhala.

Vitellone, N. (2011). Contesting compassion. Sociological Review, 59(3), 579-596. doi:10.1111/j.1467954X.2011.02013.x

Walsh, S. (2003). \& space, Note 10. In Troubling experiences: Female subjectivity and fear in teaching (pp. 175-176) (unpublished dissertation). University of Alberta, Edmonton Alberta.

Walsh, S. (2006). An Irigarayan framework and resymbolization in an arts-informed research process. Qualitative Inquiry, 12(5), 976-993.

Walsh-Frank, P. (1996). Compassion: An East-West comparison. Asian Philosophy, 6(1), 5-16.

Waves of compassion. (2013). Accessed October 9, 2013 at http://www.wavesofcompassion.ca/index.html

Whang, P. A., \& Peralta Nash, C. (2005). Reclaiming compassion: getting to the heart and soul of teacher education. Journal of Peace Education, 2(1), 79-92.

Whitford, M. (1991). Luce Irigaray: Philosopby in the feminine. New York: Routledge.

Wong, J. (2013). One year later, Raymond Taavel remembered (Global News Halifax, April 16). Accessed September 20, 2013 at http://globalnews.ca/news/485833/halifax-community-remembers-raymondtaavel/

Yao, F. (2006). There are no degrees in a Bodhisattva's compassion. Asian Philosophy, 16(3), 189-198.

\section{About the Authors}

Susan Walsh is an associate professor in the Faculty of Education at Mount Saint Vincent University and also a member of the leadership team for $W$ aves of Compassion in Halifax Regional Municipality. She teaches courses in research, literacy education, gender and literacy, and drama in education. Her research interests include: female teachers-their subjectivities and experiences (women and difficult experiences in teaching; internationally educated female teachers), feminist poststructuralist theory, innovative forms of research (artsbased research, writing as a process of inquiry, poetic inquiry, memory work/collective biography), contemplative inquiry and pedagogy, and embodied and relational ways of being and knowing. She has presented and published her work widely: for example, in Qualitative Inquiry, Qualitative Studies in Education (QSE), and Teaching and Teacher Education. Email: susan.walsh@msvu.ca Website: http://www.msvu.ca/en/home/programsdepartments/education/facultyresearch/drsusanwalsh.aspx

Fabiana González has been a research assistant with the Waves of Compassion organization since 2012, inquiring into the perceptions and manifestations of compassion in Halifax, Nova Scotia, Canada. She holds a 
Bachelor degree in advertising and public relations from the Universidad Complutense de Madrid in Spain. She is currently a graduate student at Mount Saint Vincent University (MSVU) in Halifax, Nova Scotia, Canada, where she has been awarded a merit scholarship. She is currently working on her thesis in order to complete a Master of Arts in Communication; her research focuses on phatic communication framed within a sociological perspective. At present, she is also a research assistant for the Department of Communication at MSVU working on the implementation of the Generally Accepted Practices (GAP) survey in public relations, a first time venture in Canada. Email: fabiana.gonzalez@msvu.ca

Phillip Joy has been a research assistant with Waves of Compassion since 2012, exploring what residents of Nova Scotia think compassion is and how people work with it. He holds a MSc. in Biology from Dalhousie University in Halifax, Nova Scotia. Phillip is currently completing his requirements for his professional designation in Dietetics and works as a lab instructor for the Department of Applied Human Nutrition at Mount Saint Vincent University. In his work, Phillip integrates both scientific and qualitative research perspectives. His research interests are varied; besides his work with compassion in the community, he has been involved with inquiries focused on the use of visual methods in research, GLBT concerns, medical ethics, employment and student Wellness programs, and the Women in Science and Engineering (WISE) project. He is also a practicing photographer; his first show was entitled "Playgrounds of the Faerie" (Viewpoint Gallery, 2012).Email: phillip.joy@msvu.ca and/or fyresong@hotmail.com

Website: http:// fyresongphotography.weebly.com/

Kim MacAulay, as Spiritual Life Coordinator at Mount Saint Vincent University and Co-Director of Waves of Compassion (W aves), has helped bring several initiatives to life related to compassion, spirituality, diversity, and interfaith relationships. Along with Waves, these include the Heart \& Spirit of our Communities, and most recently, Mount CARES and the UN Week of Interfaith Harmony. She has received grants from Citizenship and Immigration, Sisters of Charity and the Inspirit Foundation for some of this work. All of these initiatives are collaborative in nature, bringing together campus and community, and engaging diverse sectors of greater Halifax, including spiritual, cultural, governmental, educational and health. Kim's research interests lie in the area of compassion, spirituality, and interfaith relationships. Email: kim.macaulay@msvu.ca Website: http://www.msvu.ca/en/home/community/peaceroom/kimmacaulay.aspx 